University of Louisville

ThinkIR: The University of Louisville's Institutional Repository

Electronic Theses and Dissertations

$5-1913$

\title{
The chemical distribution of phosphorus in potato.
}

Hattie L. Heft

University of Louisville

Follow this and additional works at: https://ir.library.louisville.edu/etd

\section{Recommended Citation}

Heft, Hattie L., "The chemical distribution of phosphorus in potato." (1913). Electronic Theses and Dissertations. Paper 596.

https://doi.org/10.18297/etd/596

This Master's Thesis is brought to you for free and open access by ThinkIR: The University of Louisville's Institutional Repository. It has been accepted for inclusion in Electronic Theses and Dissertations by an authorized administrator of ThinkIR: The University of Louisville's Institutional Repository. This title appears here courtesy of the author, who has retained all other copyrights. For more information, please contact thinkir@louisville.edu. 
THE CHBMTCAL DISTRIBUTION OF PHOSPHORUS IN POTATO

\section{PHESIS}

Stabmitted to the Faculty of the college

of

ARTS AND SCIEAHCES

of the

UNIVARSITY ON-LOUISVIILS

through

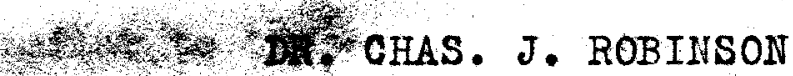

In candidacy for the Degree

"Master of Soienea"

$$
\text { by }
$$

HATPIE I. HEPT

1913 
THE CHEIICAL DISTRIBUTION OF PHOSPHORUS IN POTATO. -

The first effective impulse to a systematic investigation of the chemistry of food was given by Liebig some fifty years ago. The easliest quantitative analyses of food materials which we have found are those of potatoes reported by George Pearson' in England, 1795. In 1805, Einhoff ${ }^{2}$ made similar analyses of potatoes. He also determined several of the constituents of the ash. Liebig and his associates Playfair, Boeckman and others, in the latter hallf of the last century, made analyses of foods using methods similar to those now in use. It is interesting to observe how accurate many of their results were. These chemists were more interested, however, in the qualitative composition of foods than in quantitative analyses and made more satisfactory determinations of the ash constituents than of the organic compounds. Until the year 1880, those who wished to know about the chemical composition of food materials, had to uso analyses made in German laboratories, but since that time, interest and investigation in this subject arose in our own country, and now, since 1906, complete and exhaustive statistics compiled by Atwater and Bryant ${ }^{3}$, relative to the chemical composition and nutritive value of Tepert Arts and Manufactures 3 (1795) pp. 383-400. 2 Gehlen's Neues Journ. Chem. 4(1805) pp. 315, 455; 5(1806) p 131 3Bull. 28, U. S. D'p't. of Agr. 
all American food materials are available.

The study of the phosphates and other phosphorus compounds in food and nutrition received little attention by investigators until Forbes' and Hart ${ }^{2}$ showed that malnutrition was often attributable, not so much to a low protein diet, as to a deficiency of phosphorus. Investigation and interest in this subject was aroused. The phosphorus compounds are as definitely essential to every living cell as are the proteins, and are as fundamentally requisite for the growth, development and functions of the organism. Phosphorus was accidentally discovered by an alchemist named Brand $t^{3}$ of Hamburg, while experimenting with urine in 1669. As urine contains only a small quantity of phosphoric acid, phosphorus did not become generally known till about one hundred years later. Brandt, adhering to his original method in preparing phosphorus from urine, guarded his secret for a long time, but finally agreed to sell the secret of his manufacture 5 to a man named. Kraft. "Kraft exhibited it as one of the wonders of nature to various crowned heads, among. them, in the year 1677, to King Charles II of England." 6 Kunkel skillfully elicited the coveted information from Kraft and published, in the year 1678, a pamphlet on this remarkable product. In those early days, phosphorus was a very

'Bul1.201, Ohio Exp. Sta. (1909)

a Bull. 5, Wis. Exp. Sta. (1908)

3 Gmelin's Hand-book of Chemistry, Vol II, p. 102. 4Hammersten's Physiol. Chem. p. 722.

5The process consisted in distilling evaporated urine with sand in clay retorts.

6Roscoe and Schorlemmer, Treatise on Chem. Vol I. p.458. 
costly substance and was valued as the most interesting chemical substance known. In 1769, Gahn showed it to be an essential constituent of bone. Scheelel, profiting by this later discovery, made phosphorus from bone ash. At one time, phosphorus was considered a compound body containing "phlogiston" and an acid, but Lavoisier ${ }^{2}$ in 1780, showed that when phosphorus is burned in the air, the acid produced weighed more than the phosphorus itseli. It seems strange that the sources of Brandt's phosphorus and Gahn's did not indicate to the early chemist the physiological importance of the element.

Phosphorus occurs in the inorganic world as phosphoric acid united with bases, chiefly with the alkalies and alkaline earths, and enters the plant only in this form. Plants are able to utilize the inorganic materials of the soil and synthesize the complicated substances which serve as a source of phosphorus supply for animals. The phosphorus - compounds of animal tissues have been much more extensively studied than those of plant tissues, but their extreme complexity has baffled the efforts of chemists to such an extent that the true chemical nature of many such substances is very imperfectly understood.

Phosphorus exists in the animal body in organic and inorgandc forms. In the nervous system, and playing an important part in its structure, we find a variety of

IVide report by Juries of International Exhibition, London, ¿ Opuscules Physiques et Chemiques, 1774. 
compounds collectively called, lecithans, substances resembling fats, but distinct in their composition. In these substances, phosphorus appears as phosphoric acid, in combination with glycerol, fatty acids and various basic substances. It occurs in organic combination in the nucleoproteins found chiefly in the cell nuclei and in protoplasm. In the inorganic form, phosphorus is combined with the alkaline earths forming one of the most important constituents of the human skeleton. According to Voit's estimate, the skeleton contains about 1400 grams, muscle 130 grams, and brain and nerves 12 grams of phosphorus. One would naturally spppose that wherever the building up of such tissues is concerned, a large supply of phosphorus will be required. The recognition of this necessity for proper phosphorus supply for the animal, has led to considerable investigation of the phosphorus compounds in vegetable foods. The most abundant of the phosphorus compounds of food, thus far studied, may be grouped under four heads: the phosphorized proteins; phosphorized fats; phytates and inorganic phosphates. It appears that all four types of phosphorus compounds are utilized in nutrition, but that considerable differences probably occur in their nutritive value.

The phosphoproteins and phosphorized fats as found both in plants and animals are no doubt formed from simple proteins, fats and phosphorus compounds. Naxwelll has IAmer. Chem. Jour. 13, 16; 15, 135. 
made important observations to this effect on the synthesis of phosphorized fats. Paton! has also made investigations as to their formation with similar conclusions.

The phytates, occurring in vegetable food materials, have only recently been recognized and are still under active investigation. They are considered simpler organic derivatives of phosphoric acid, such as "anhydro-oxymethylene di-phosphoric acid", (phytic acid). According to Winterstein $^{2}$ there exists in the vegetable kingdom phosphorus compounds which on cleavage yield inosite and phosphoric acid. Posternak ${ }^{3}$ has given this substance the name "phytin". Such substances are acid in nature and are combined, with metals, mostly magnesium, bụt also calcium, potassium and sodium. The phytins have been found only in young and growing vegetable cells and are abundant sources of phosphorus for animals. Phosphorus exists largely in this form in wheat bran, and in this form is readily absorbed from the digestive tract.

Plants depend on the inorganic phosphates and convert them into the above-mentioned groups of organic compounds, but animals can absorb only a limited amount of the element in inorganic combination. Forbes ${ }^{4}$ and Hart ${ }^{5}$ in a series of experiments, demonstrated that calcium phosphate, when taken

I Journ. of Physiol. 23, 333.

zeitschr. f. physiol. Chem., xxii, p.90. 3Compt. rend. acad. d. sci., cxxxvii, pp. 202, 337, 439, 1903. 4Bull. 201, Ohio Exp. Sta. (1909).

5pul1. 1, Wis Exp. Sta. (1909). 
in conjunction with organic phosphorus compounds can be utilized by the bony tissue. Mac Collum', as a result of his investigations, thinks that the inorganic phosphates can satisfactorily fulfill all the requirements of the animal organism. From these investigations, we conclude that simple phosphates are not without nutritive value. To be most useful, dietary standards should take into account not only the amounts of phosphorus required by the body, but the kinds of phosphorus a given diet will furnish. Analyses of foods, as published, show only total khosphorus, but as far as we are aware, not what proportion of the four kinds. "The interest and possible importance of the knowledge of the distribution of phosphorus has prompted this effort. This work is largely a trial of methods for such an analysis.

The common potato, by far the most popular and important food of both the American and European diet, so far surpasses alloother tubers and roots in importance, that its composition and nutritive value have been carefully studied not only in this country but in Europe. The pqtato was chosen for this particular work, because of its importance as an article of diet, and because it is hoped that a study of phosphorus distribution in different stages of the growth of the potato plant from tubers may throw light on the course of phosphorus in plants from the inorganic material absorbed from the soil, to the complex synthetic products eventually produced, the potato representing a complete PBull 8, Wis. Agr. Exp. Sta. 
supply of nutrient material sufficient for considerable growth of plant structure.

\section{EXPERIMENTAL PART.}

Preparation of Material.

A half bushel of potatoes, as purchased, was thoroughly cleaned (scrubbed), and then peeled as ordinarily prepared in the kitchen. The pairings were left to partially dry in the air, while the edible portion was ground as fine as possible, to facilitate rapid evaporation. The drippings from the grinding process were carefully preserved and put in large evaporating dishes. The peeled potatoes, exposed to the air, changed in color to a reddish-brown, and as the process of drying 'continued, to a black brown. This change was due to the action of enzymes in the potato, which in the presence of the oxygen of the air, act upon the tannin-like bodies in the tuber. The mass was then spread upon glass plates cut to fit into a long narrow box. An electric fan was employed to drive air through a heated galvanized iron tube connected with this box. The temperature of the air in this box was approximately $35^{\circ} \mathrm{C}$; higher temperature being avoided to prevent dextrinizing the starch. A few hours sufficed to drive out the greater portion oif water, but the process was continued three days to complete the drying. The drippings were dried in a similar way, and the residue combined with the main mass.

Weight of dried mass _.................. $1730 \mathrm{~g}$.

Weight of dried residue from drippings _.. $310 \mathrm{~g}$. Total weight _.... $2040 \mathrm{~g}$. 
Weight of edible portion (orjginal) _. $10000 \mathrm{~g}$.
Weight of edible portion (dried)__._. $2040 \mathrm{~g}$.
Loss in drying $\ldots 960 \mathrm{~g}$.

The moisture in edible portion, according to these figures, was 79.6 per cent. The parings were also ground in a chopper and dried in the same manner.

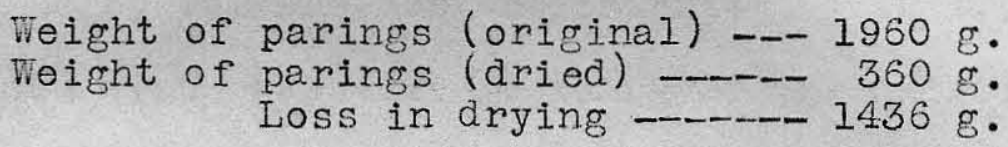

The percentage of moisture in parings according to these figures, was 79.9.

The dessicated material of edible portion and parings was separately ground in a mortar, and sifted through seventy mesh wire gauze, until'all the particles were so reduced that they passed through the gauze. Considerable time was required for the process. The edible portion, as conpleted, was a light gray powder; the parings, a light brown and of a softer and finer texture.

Moisture Determination.

Quantitative determinations of moisture were made with the edible portions and parings. The portions were successively heated in an air-bath for periods of two hours at a temperature of $95^{\circ}-105^{\circ} \mathrm{C}$, , cooled in a dessicator and weighed. Constant weight was obtained after four intervals of drying.

$5.4836 \mathrm{~g}$. of edible substance showed a loss of $.5628 \mathrm{~g}$. Percentage loss, 10.3 .

$5.0817 \mathrm{~g}$. of parings showed a loss of _.......... Percentage loss, 12.1 
Determination of Total Phosphorus.

Total phosphorus determinations of the edible portion and parings were first made. After experimenting with various methods for decomposing the organic material, that of boiling with concentrated sulphuric and nitric acids was found to be by far the most efficient. Wuch trouble was experienced with excessive frothing of the material during decomposition. A rather detailed description, though apparently superfluous, will be appreciated by one performing this phase of the work.

In each case a woighed quantity of the prepared substance was used. Two or three grams of the material was put in a five hundred c.c. digestion flask and ten c.c. of concentrated sulphuric acid and ten c.c. of concentrated nitric acid added. The mixture was shaken and boiled until the evolution of nitric oxide fumes ceased. A. Opon Eooling, another several gram portion of material was added and the - flask shaken. The action began at once and continued for some time without the application of any heat. When the action subsided, heat was applied and the boiling continued until the mass darkened and charred. Then ten c.c. of nitric acid was added and the mixture boiled. In a short time the nitric oxide ceased forming and a clear brownish liquid resulted. Upon cooling slightly, another snall portion of material was added and the flask shaken; the heat of its own oxidation again being sufficient to maintain action. If heat is applied at this time, frothing will invariably result. This is likewise the case if the material 
and acid are added simultaneously. The purpose of adding the acid and the material in small amounts alternately, is to avoid the accumulation of a gummy residue which results on partial decomposition of the organic matter. If, during the process, upon addition of nitric acid, the resulting liquid does not clarify, it is expedient to add more acid and boil until this oocurs. By following this detailed method, no danger of any loss is encountered, and time is saved, for the operation can readily be carried on as a secondary matter while the attention is concentrated on other work.

This method was a great improvement over one previously made with the parings when the entire quantity (twenty grams), was put in the digestion flask and ten c.c. of sulphuric and fifteen c.c. of nitric acids added. Almost instantly, frothing ensued, and much time was consumed in watching, cooling and warming the flask as the tendency to froth continued almost to the end of the operation. For so large a portion to be burned at one time, a liter flask is scarcely adequate.

The time consumed for the complete operation was perhaps seven hours when twenty grams of material was used. In the case of the edible portion, the resulting acid mixture was clear and colorless, but with the parings, a milky precipitate settled upon cooling, although the supermatant liquid was quite clear. It was concluded that this was an inorganic redisue due to the large amount of inorganic material in the parings.

The contents of the digestion flasks was removed to a beaker and diluted with the rinsings (four) from the 
flask, neutralized with concentrated ammonium hydroxide, then acidified with concentrated nitric acid. Upon warming, $125 \mathrm{c.c}$. ammonium molybdate solution ( $75 \mathrm{~g}$. crystallized ammonium molybdate to liter), was added, and enough ammonium nitrate crystals to make a ten per cent concentration. After warming to $60^{\circ} \mathrm{C}$, and maintaining the temperature for several hours, the ammonium phospho-molybdate was filtered. The operation was continued in the usual manner and the phosphorus weighed as magnesium pyrophosphate. The results of the experiments are given in the following table.

\section{TABLE I.}

Total Phosphorus Estimated in Edible Portion and Parings.

Gms. of edible $\begin{array}{llllll}\mathrm{Mg}_{2} \mathrm{P}_{2} \mathrm{O}_{7} & \mathrm{P}_{2} \mathrm{O}_{5} & \mathrm{P} & \mathrm{P}_{2} \mathrm{O}_{5} & \mathrm{P}\end{array}$ portion used grams grams grams per cent per cent

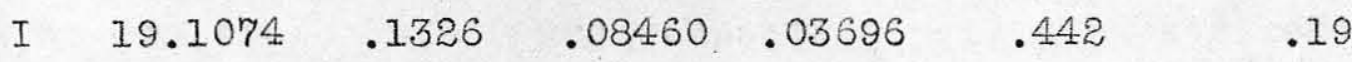

$\begin{array}{llllll}\text { II } 20.9060 & .1518 & .09684 & .04231 & .463 & .20\end{array}$

Av. $20.0067 \quad .1422 \quad .09072 \quad .03963 \quad .453 \quad 195$

-Gms. of parings used

$\begin{array}{lllllll}\text { I } & 19.6512 & .2330 & .1490 & .06494 & .758 & .33 \\ \text { II } 20.1748 & .2258 & .1440 & .06294 & .713 & .31 \\ \text { AV. } 19.9130 & .2294 & .1465 & .06394 & .735 & .32\end{array}$

According to published statistics', the maximut amount of $\mathrm{P}_{2} \mathrm{O}_{5}$ to be expected in 100 grams of undried edible portion is .2070 grams, the average,.1104 grams, and the minimum, .0690 grams. By the previous experiment on moisture determination, we may estimate 100 grams of edible 
substance as equal to 20 grams of the dried material, hence, the percentage of $\mathrm{P}_{2} \mathrm{O}_{5}$ in the undried edible portion was .0906. By comparison, the potato used falls somewhat short of the average. The noticeable feature of this part of the work is the large content of phosphorus in the parings, as compared with that of the edible portion. If these phosphorus compounds are in available forms for the organism, it is evident that a large part of the food value, in the form of mineral matter, is lost in the common methods of preparation, i.e., of peeling the potato, a point which has been mentioned by Dr. Langworthy'.

Outline of Method for Estimation of Four Kinds of Phosphorus Compounds.

Regarding the phosphorus compounds of the potato as divisible into four groups: i.e. (I) phosphorized fats (phosphatides); (2) non-protein and non-lipoidal organic derivatives of phosphoric acid and phosphates -(phytins); (3) inorganic phosphates; (4) phosphorized proteins (nucleoproteins, lecithoproteins and phosphoproteins), the scheme of analysis employed was as follows: Fraction 1-Extraction of material with hot alcohol to obtain lipoid compounds.

Fraction 2-Digestion of material with 0.2 per cent hydrochloric acid and precipitation with 95 per cent alcohol to obtain the organic phosphorized compounds of the phytin group. In this paper, the the material obtained (subject to investigation

IFarmers Bull. 295, p. 8, U. S. Dept. of Agriculture. 
and study prior to the establishment of its identity), we designate as, "acid soluble-alcohol insoluble" substances.

Fraction 3-Evaporation of the acid alcohol filtrate obtained. after removing the alcohol insoluble substances, leaving a residue containing inorganic phosphates and possible organic phosphorus compounds, we designate this fraction as, the 'acid solublealcohol soluble" materials.

Fraction 4-Determination of the residual phosphorus contained in the mass after the alcoholic extraction for lipoids and the 0.2 per cent hydrochloric acid digestion for phytates. This residual phosphorus is presumably protein phosphorus.

Analyses of Edible Portion.

\section{(a) Lipoid Extractions.}

As the solubilities of lipoids differ with hot and cold alcohol, hot alcohol was used in this determination to insure as complete an extraction as possible. The Erlenmeyer flask containing a weighed amount of dessicated material was three fourths submerged in hot water, to obviate the annoying bumping which a slight immersion did not prevent. The temperature of the water-bath was gradually raised until the alcohol boiled vigorously for five minutes. The flask was then removed, shaken and replaced for several minutes in the water bath. After filtering through a hotwater funnel, the residue was returned to the flask, more 
alcohol added and the process continued five times. The five filtrates were then combined. On cooling, some material, (monophosphatides?) settled out. The alcoholic extract was then gradually evaporated from a distilling flask on a water bath, and the lipoidal residue was weighed. By dissolving the lipoid in concentrated nitric acid and rinsing with the same liquid, it was completely removed to a $\mathrm{Kjel-}$ dahl digestion flask. About ten c.c. of concentrated sulphuric acid was added and the contents boiled. When the mass darkened and charred, the heating was discontinued and on cooling, more nitric acid was added and the boiling resumed. When the mixture was thoroughly clear and colorless, the operation was stopped. The organic material was completely decomposed in about two hours. On cooling the contents were removed with repeated washings to a beaker, neutralized with concentrated ammonium hydroxide, faintly acidified with nitric acid and the phosphates determined in the usual. The results of five determinations follow. ( see p 15). In regard to the discrepancies in the analyses of the first three samples, see page 27.

An alcoholic extract of the edible portion was taken for a study of the physical properties of the substance. After evaporation the alcohol the residue was of a dark brown color, and of a waxy consistency. The odor was unmistakably that of lipoidal substances. It was soluble in chloroform and ether. Qualitative tests showed nitrogen and phosphorus present. A test for protein was negative. After boiling a few minutes with sodium hydroxide solution, a marked 
TABLE II.

Fraction 1 (Lipoid) in Edible Portion.

\begin{tabular}{|c|c|c|c|c|c|c|c|c|c|}
\hline No. & Gms. used & $\begin{array}{r}\text { Lipoid } \\
\text { grams }\end{array}$ & $\begin{array}{l}\text { Pct. } \\
\text { Iipoid }\end{array}$ & $\begin{array}{c}\mathrm{Mg}_{2} \mathrm{P}_{2} \mathrm{O}_{7} \\
\text { grams }\end{array}$ & $\begin{array}{l}\mathrm{P}_{2} \mathrm{O}_{5} \\
\text { grams }\end{array}$ & $\begin{array}{c}P \\
\text { grams }\end{array}$ & $\begin{array}{l}\text { Pct. } \mathrm{P}_{2} \mathrm{O}_{5} \\
\text { in iipoid }\end{array}$ & $\begin{array}{l}\text { Pct. P in } \\
\text { lipoid }\end{array}$ & $\begin{array}{l}\text { Pet Frac I P } \\
\text { dry potato. }\end{array}$ \\
\hline$I$ & 99.6075 & 1.2462 & 1.25 & .0139 & .0087 & .0039 & 0.715 & .31 & .0039 \\
\hline II & 100.4156 & 1.6427 & 1.63 & .0251 & .0161 & .0074 & 0.974 & .45 & .0074 \\
\hline III & 99.5848 & 2.6688 & 2.67 & .0212 & .0135 & .0061 & 0.509 & .23 & .0061 \\
\hline E & 100.7237 & 2.9783 & 2.96 & .0731 & .0465 & .0204 & 1.56 & .68 & .0202 \\
\hline & 101.0142 & 2.0835 & 2.06 & .0586 & .0374 & .0161 & 1.79 & .79 & .0162 \\
\hline
\end{tabular}


reduction of Fehling's solution was obtained.

(b) Acid soluble-alcohol insoluble substances.

Assuming the presence of phytin in potatoes and depending upon the methods pursued by Anderson' in his preparation of this organic phosphorus compound from wheat bran, the lipoid-free residue let after making the alcoholic extractions was dried in an air bath $\left(80^{\circ}-85^{\circ} \mathrm{C}\right)$, and digested with .2 per cent hydrochloric acid at room temperature over night. The extract, after straining through a cloth, was filtered through hardened filter paper. Much dificulty was encountered in filtering, as a slime continually clogged the paper. The filtrate, of a dark amber color, was precipitated with four volumes of 95 per cent alcohol. An equal volume of alcohol was found to be insufficient, but upon the addition of four times the volume, complete precipitation was obtained. A white flakey substance appeared throughout the liquid which upon standing, settled. The alcohol was decanted through hardened filter paper, reserving just enough of the acid alcohol to preserve the precipitate from moulding. Four more extractions with 0.2 per cent hydrochloric acid were made, and the procedure continued as in the first extraction. All five precipitates were then combined and the acid alcohol completely filtered off. The substance was purified by dissolving in 0.2 per cent hydrochloric acid, precipitating with alcohol (four volumes of aloohol used), and filtering through hardened paper. The final product had darkened considerably in the light. By means of a spatula, the material was completely removed to a watch glass I Journ. of Biol. Chem. Vol. XII, p 453. 
and dried in a vacuum dessicator over sulphuric acid in the dark. A dark gray, powdery substance sesulted.

Its aqueous solution was acid to litmus paper. Qualitative tests showed phosphorus present, but sulphur and nitrogen tests were negative, as was also the biuret test. After boiling with hydrochloric acid and neutralizing, the substance reduced Fehling's solution and gave Bial's reaction for pentoses. An iodine test for dextrine was positive.

Qualitative phosphorus determinations were made. Difficulty in oxidizing this material was experienced, as it was very resistant. Even with small quantities excessive frothing was with difficulty prevented. Several hours were always required to complete the operation, but a clear, colorless product was obtained in each case. In Determination $V$, crystals were observed in the $\mathrm{Kjeldahl}$ flask after cooling, but these disappeared on the addition of water. The magnesium pyrophosphate had a slight reddish tinge in every case, which persisted even after reprecipitation and oxidation ith nitric acid. Tabulation of results follows on the succeding page.

(c) Acid soluble-alcohol soluble Phosphorus Compounds.

The alcoholic acid filtrate from the acid solublealcohol insoluble was distilled to about $83^{\circ} \mathrm{C}$. The solution, which became much darker in color was in this manner reduced to about a liter. This was added in small quantities (50 ce) to a Kjeldahl digestion flask and completely evaporated. A black, gummy mass resulted. The decomposition of this matter with nitric and sulphuric acids is exceedingly trying, owing to the concentration of or ganic materials, and great caution 
TABLE III.

Fraction 2, (Acid soluble-alcohol insoluble), in Edible Portion.

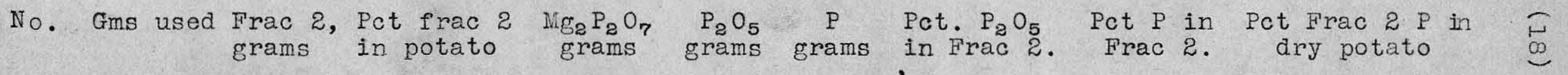

$\begin{array}{llllllllllllll}\text { I } & 99.6075 & .9815 & .98 & .0185 & .0118 & .0052 & 1.2 & .0052\end{array}$

$\begin{array}{lllllllllllll}\text { II } 100.4156 & .9842 & .98 & .0102 & .0072 & .0029 & 0.73 & .0028\end{array}$

II $99.5848 \quad 1.3017 \quad 1.30$

$0 \quad 0$

$\circ$

○

IV $100.7237 \quad 1.4536$

1.44

.0648

$.0413 \quad .0180$

2.84

1.24

.0179

V $101.0142 \quad 1.5426$

1.52

$.0525 \quad .0335 \quad .0146$

2.18

.95

.0144

The percentage of phosphorus is much lower than that found in the phytins'.

- Determination lost.

I Journ. of Biol. Chem. Vol. XII, p 449. 
is necessary, for if both acids are added at once, as before, and in the usual quantities, $(10$ c.c. of sulphuric and 10 c.c. of nitric acids), the heat spontaneously produced will cause a frothing too great to be controlled, so it was found expedient to add but $3 \mathrm{c} . c$. of sulphuric acid and the same of nitric acid and allow the flask to remain in a cold bath. Upon shaking, similar quantities of acid were successively added, and the flask kept cool in the bath. After 15 c.c. of each had been added, the flask was left in the bath over night. By the next morning, the black, gummy mass had completely dissolved, and was ready for boiling. The boiling was stopped when the mass was seen to darken and char, and then more nitric acid was added. The process was continued until the mixture was clear and colorless after prolonged heating, and quantitative phosphorus determirations were made as usual. Tabular results follow:

\section{TABLE IV.}

Fraction 3 (Acid soluble-alcohol soluble) in Edible Portion.

$\begin{array}{lrlccc}\text { No. } & \text { Gms. used } & \begin{array}{c}\mathrm{Mg}_{2} \mathrm{P}_{2} \mathrm{O}_{7} \\ \text { grams }\end{array} & \begin{array}{c}\mathrm{P}_{2} \mathrm{O}_{5} \\ \text { grams }\end{array} & \begin{array}{c}\mathrm{P} \\ \text { grams }\end{array} & \begin{array}{c}\text { Pct. Fraction 3 } 3 \\ \text { in dry potato. }\end{array} \\ \text { I } & 99.6075 & .2315 & .1477 & .0645 & .0648 \\ \text { II } & 100.4156 & .2968 & .1893 & .0828 & .0824 \\ \text { III } & 99.5848 & .2389 & .1524 & .0666 & .0669 \\ \text { IV } & 100.7237 & .2975 & .1854 & .0829 & .0823 \\ \text { V } & 101.0142 & .3390 & .2162 & .0945 & .0935\end{array}$

(d) Residual Phosphorus.

After the acid extractions the residue of potato was dried in the hot bath at a temperature of $65^{\circ} \mathrm{C}$. The substance 
dries in limps and because of this, oxidation of it is troublesome. Nitric and sulphuric acids were used as before. The same care must be exercised in adding small quantities to the digestion flask and if these additions are made while the cottents are warm, decomposition will occur quickly. The nitric acid was added in five c.c. portions and the same care exercised as in the method detailed for the total phosphorus determination. It was necessary to use at least $20 \mathrm{c.c}$. of sulphuric acid and about $200 \mathrm{c.c}$. of nitric acid. Some time is required for this decomposition, but clear, colorless mixtures are eventually obtained.

\section{TABLE $V$.}

Fraction 4 (Residual Phosphorus) in Edible Portion.

$\begin{array}{lrlccc}\text { No. Gms. used } & \begin{array}{c}\mathrm{Mg}_{2} \mathrm{P}_{2} \mathrm{O}_{7} \\ \text { grams }\end{array} & \begin{array}{l}\mathrm{P}_{2} \mathrm{O}_{5} \\ \text { grams }\end{array} & \begin{array}{c}\mathrm{P} \\ \text { grams }\end{array} & \begin{array}{c}\text { Pct. Fraction 4 } \\ \text { in dry potato. }\end{array} \\ \text { I } & 99.6075 & .2541 & .1621 & .0709 & .0712 \\ \text { II } & 100.4156 & .1888 & .1204 & .0526 & .0523 \\ \text { III } & 99.5848 & .2032 & .1294 & .0567 & .0569 \\ \text { IV } & 100.7237 & .2572 & .1647 & .0717 & .0711 \\ \text { V } & 101.0142 & .2816 & .1786 & .0785 & .0777\end{array}$

The loss of weight in grams in the dried potato by the successive extractions was noted in several determinations. The error in these figures, attributable to incomplete drying, is doubtless large, but they are inserted for the sake bf indicating roughly the loss of material in the various extractions. The loss noted in the alcoholic extractions, consists mostly of water. 
TABLE VI.

Loss in Grams by the Various Extractions.

Original Wt. after Dissolved in wt. after Dissolved in weight alc. ext. alc. ext. acid ext. $0.2 \% \mathrm{HCl}$.
Sample V $101.0142 \quad 91.2106$
9.8036
71.6422
19.5684

Sample VI $100.1759 \cdot 91.7386$

8.4391

76.0694

24.1165

Sample I I parings

99.9240

88.9474

10.9766

73.0332

15.9142

Tabular results of the phosphorus distribution in the four fractions of the five determinations are given, with the percentage distribution in Sample $\mathrm{V}$, in order that we may appreciate the relation of the phosphorus compounds as found in potatoes, to each other and to the sum total as previously estimated, ( $p$ 11.).

\section{TABLE VII.}

A Comparison of the Total Phosphorus with the Sum of the Four Fractions.
I
II
III
IV
$\mathrm{V}$

Fractions 99.6075100 .415699 .5848100 .7237 .101 .0142 Pct.in Sam.V.

\begin{tabular}{|c|c|c|c|c|c|c|}
\hline 1- Lipoid & .0039 & .0074 & .0061 & .0204 & .0164 & 8.2 \\
\hline - Acid sol- & .0052 & .0029 & 0 & .0180 & .0146 & 7.3 \\
\hline $\begin{array}{l}\text { Acid sol- } \\
\text { alc. sol }\end{array}$ & .0645 & .0828 & .0666 & .0829 & .0945 & 47.25 \\
\hline - Residual & .0709 & .0526 & .0567 & .0717 & .0785 & 30 \\
\hline Total & .1445 & .1457 & 0 & .2050 & .2090 & 102. \\
\hline $\begin{array}{l}\text { al. from to- } \\
\text { tal P deter. }\end{array}$ & .1868 & .1985 & 0 & .1993 & .2 & \\
\hline
\end{tabular}

- Determination lost. 
Extractions of Phosphorus Compounds and Analyses of Parings.

As the total phosphorus content of the parings far exceeded that of the edibie portion, interest naturally arose as to the nature of the phosphorus compounds present, and their relation to those of the edible portion. The almost universal castom of preparing potatoes by peeling and discarding the parings as refuse, makes this investigation all the more pertinent. Perhaps at no time in the history of our country has the subject of economics, the nutritive value of foods, and the general utilization of all waste materials been of such vital interest as now, and we. trust an investigation in this particular case, will not appear superfluous and without practical value. Quantitative extractions and analyses of all four kinds of phosphorus compounds were accordingly made. (a) Lipoid Bxtraction.

The extraction of lipoidal substances presented a marked and interesting contrast to the edible portion. The hot alcohol, when filtered, showed upon a very slight cooling, a thin nebula, thraughout. This increased rapidly with the cooling from a film to a thick cloud, which resolved itself into a heavy precipitate at the bottom of the beaker. There was no apparent decrease in the amount of this substanice in the four ensuing extractions, so three more were deemed necesary. Even the last filtrate did not present an entire transparency on cooling. These seven extractions were combined as heretofore, and the amount of residue left by evaporation of the alcohol was noted. The physical properties accorded with those of the material similarly extracted from 
the edible portion. Quantitative phosphorus determinations were made. From Table VIII, p. 24, it is seen that the lipoidal substances, as obtained from the parings, though greater in quantity, approximately three times, are much less rich in phosphorus than the lipoidal substances from the edible portion.

(b) Acid soluble-alcohol insoluble substance.

After the alcoholic extraction for lipoid substances hiad been made, the residue was dried and digested with 0.2 per cent hydrochloric acid as in Fraction 2 , edible substance. This extraction was markedly great in quantity, and of a dark brown color. Five extractions were made, the total combined, and purified by dissolving in 0.2 per cent hydrochloric acid and precipitating with alcohol. The resulting precipitate bore a decided resemblence to the acid soluble-alcohol insoluble extraction of wheat bran, ( $p$ 36), in physical appearance and rapid manner of settling. It was once more purified. The precipitate was decidedly white, but during the filtration it darkened rapidly as in Fraction 2 , edible portion. After drying in a vacuum desiccator and rinding in a mortar, a fine, brown, powdery substance resulted. The aqueous solution was acid to litmus paper. When boiled with concentrated hydrochloric acid and neutralized, it reduced Fehling's solution and gave a positive test for pentoses with Bial's reagent. A quantitative phosphorus determination was made. Results appear in table IX, page 24.

It will be observed that the percentage of phosphorus in the acid soluble-alcohol insoluble substance is much higher than that in Fraction 2 of the edible substance, p. 18. 
TABLE VIII.

Fraction 1, (Lipoid), in Parings.

\begin{tabular}{|c|c|c|c|c|c|c|c|c|c|c|}
\hline No. & Gms used & $\begin{array}{r}\text { Lipoid } \\
\text { grams }\end{array}$ & $\begin{array}{l}\text { Pot. Lipoid } \\
\text { in parings }\end{array}$ & $\begin{array}{l}\mathrm{Mg}_{2} \mathrm{P}_{2} \mathrm{O}_{r} \\
\text { grams }\end{array}$ & $\begin{array}{r}\mathrm{P}_{2} \mathrm{O}_{5} \\
\text { grams }\end{array}$ & $\frac{\mathrm{P}}{\text { grams }}$ & $\begin{array}{l}\text { Pct. } \mathrm{P}_{2} \mathrm{O}_{5} \\
\text { in iipoid }\end{array}$ & $\begin{array}{l}\text { Pet P in } \\
\text { Iipoid }\end{array}$ & $\begin{array}{l}\text { Pet } \\
\text { in }\end{array}$ & $\begin{array}{l}\text { Frac } 19 \\
\text { parings }\end{array}$ \\
\hline$I$ & 99.924 & 7.8012 & .0783 & .0490 & .0312 & .0136 & .398 & .173 & & .0136 \\
\hline II & 99.0378 & 7.0814 & .0715 & .0416 & .0265 & .0116 & .370 & .162 & & .0117 \\
\hline
\end{tabular}

Fraction 2, )Acid soluble-alcohol insoluble) in Parings.

\begin{tabular}{|c|c|c|c|c|c|c|c|c|}
\hline Gms used & $\begin{array}{l}\text { Frac } 2, \\
\text { grams }\end{array}$ & $\begin{array}{l}\text { Pct frac } 2 \\
\text { in parings }\end{array}$ & $\begin{array}{l}\mathrm{Mg}_{2} \mathrm{P}_{2} \mathrm{O}_{7} \\
\text { grams }\end{array}$ & $\begin{array}{r}\mathrm{P}_{2} \mathrm{O}_{5} \\
\text { grams }\end{array}$ & $\begin{array}{c}\text { P } \\
\text { grams }\end{array}$ & $\begin{array}{l}\text { Pct } \mathrm{P}_{2} \mathrm{O}_{5} \\
\text { in frac } 2 .\end{array}$ & $\begin{array}{r}\text { Pet } P \text { in } \\
\text { frac } 2 .\end{array}$ & $\begin{array}{l}\text { Pct. frac } 2 \\
\text { in parings }\end{array}$ \\
\hline 99.0378 & .7142 & .7212 & .0783 & .0499 & .0219 & 6.99 & 3.06 & .0221 \\
\hline
\end{tabular}


Whether this is due solely to the additional precipitation or to the different composition of the substance itself is not known. By comparing the phosphorus percentage of the twice purified substance with that similarly prepared from wheat bran, we infer this substance from the parings is not phytin alone. From later work ( $p$ 29), we include that some protein material is also present. When this is completely removed and the resulting substance purified, there results a substance high in phosphorus content, which is either very similar to, or identical with the phytin.

(c) Acid soluble-alcohol soluble material.

After distilling the alcohol as usual to $83^{\circ}$, the residue, about a liter, was evaporated in a Kjeldahl digestion flask. The resulting substance was similar to that of the edible portion, i.e., black and gummy. Sulphuric acid was added and after complete colling, the nitric acid. The same caution was observed in the treatment of this mass, as with the edible portion. The decomposition required the same time. A small white residue was observed in the bottom of the flask and the supernatant liquid, though transparent, had a slightly greenish-yellow color. After removing to a beaker, neutralizing with concentrated ammonium hydroxide and acidifying with nitric acid, 150 c.c. ammonium molybdate was added and the usual phosphorus determination made.

\section{TABLE $X$.}

Fraction 3 (Acid soluble-alcohol soluble) in parings.

$\begin{array}{ccccc}\text { Gms. used. } & \begin{array}{c}\mathrm{lg}_{2} \mathrm{P}_{2} \mathrm{O}_{7} \\ \text { grams }\end{array} & \begin{array}{c}\mathrm{P}_{2} \mathrm{O}_{5} \\ \text { grams }\end{array} & \begin{array}{c}\mathrm{P} \\ \text { grams }\end{array} & \begin{array}{c}\text { Pct. Frac. 3 } \\ \text { in parings. }\end{array} \\ 99.0378 & .4727 & .3011 & .1313 & .1326\end{array}$


(d) Residual Phosphorus.

The mass was dried in the air bath at $65^{\circ}$; then oxidized as before in a kjeldahl digestion flask. The procedure was the same as for fraction four of the edible portion. When the decomposition was finished, a white residue was noted, but the liquid above was clear and colorless. A quantitative phosphorus determination was made.

. TABLE XI.

Fraction 4, (Residual Phosphorus) in Parings.

\begin{tabular}{|c|c|c|c|c|}
\hline & $\begin{array}{l}{ }_{\text {grams }} \mathrm{g}_{2} \mathrm{P}_{2} \\
\text { gram }\end{array}$ & grams & grams & $\begin{array}{l}\text { Pct. Frac. } 4 \\
\text { in parings. }\end{array}$ \\
\hline 99.0376 & .4462 & .2846 & .1243 & .1255 \\
\hline
\end{tabular}

TABLE XII.

A Comparison of the Total Phosphorus of Dessicated Parings with the Sum of the four Fractions.

$$
\text { Dessicated Parings, }(99.924 \text { g.). }
$$

Fractions Phosphorus Pct. Distribution in Sample.

$\begin{array}{lll}\text { I-Lipoid } & .0136 & 4.36 \\ \text { 2-Acid sol- } & .0219 & 7.03 \\ \text { 3-Acid sol- } & .1346 & 43.21 \\ \text {-alc sol. } & .1243 & 39.91 \\ \text {-Residual P } & .124 \\ \text { Total } & .2944 & 94.71\end{array}$

Cal. from total Phos. Deter. 
The Nature of the Different Fractions.

The results obtained in the five determinations of edible portion show a great variance, especially in the amounts of lipoid and acid soluble-alcohol insoluble material, with.

a marked increase in these fractions in samples four and-five, whereas rather closely duplicated results were obtained in the extractions of the parings. The explanation may lie in the fact, that familiarity with the methods produced greater skill in manipulation and technique, and thereby ensured more thorough and complete extractions.

1- Lipoid Fractions.

The physical characteristics of the lipoids in each determination were practically the same, although, in the case of the parings the color seemed darker. This, however, may be due to the large quantity obtained in the latter case. The percentage of phosphorus seems low. No attempt was made in this investigation to separate the constituents of this lipoid fraction. Whether or not the kinds of lipoid present in the potato are of such a nature as to influence its nutritive value, suffice it to say, the results obtained in the edible portions and parings are so widely variant that an investigation as to their nature seems to us quite worth while.

2- Acid soluble-alcohol insoluble Fractions. The tests, cade upon the substance, (phytin?), soluble in 0.2 per cent hydrochloric acid, and insoluble in 95 per cent alcohol, were comparable with those made by Anderson on phytin from wheat bran, but the percentage of 
phosphorus was much lower. The range of percentages in the seven determiation calls an inquiry as to whether or not this was a single substance or an admixture. An iodine test for dextrine in this fraction was positive.

In his work on wheat bran, Anderson mentioned the presence of certain substances which caused "subsequent purification difficult, especially the filtrations." He suggested as an explanation of this that certain dissolved proteins are contained in the 0.2 per cent hydrochloric acid and that these substances rendered insoluble, form a slimy mass which clogged the filter paper. The difficulty was identical in the potato extraction, to such an extent, that the filter papers had to be renewed in order to secure a filtration. Anderson found that the suggestion made by Dr. Jordan, to precipitate the bran extract with tannic acid, obviated this difficulty, so the method was tried in this work.

Tannic acid Method.

New portions of about one hundred grams each of the edible portion and parings were taken and lipoid extractions made. Then, after digesting each with 200 c.c. of 0.2 per cent hydrochloric acid over night, the filtrate was precipitated with a 10 per cent solution of tannic acid, 100 c.c.being used. A fine, voluminous precipitate of milky color appeared instantly. This was allowed to settle over night. By the next day it had assumed a thick waxy consistency, and had a dark brown.color. It could readily be rolled into a uniform mass with a stirring rod. The liquid was decanted as before through ordinary filter paper (doubled) and then 
through hardened filter paper. The complete filtration was accomplished in thirty minutes, whereas hours were consumed in the usual process. The tannic acid was evidently effective in removing the cause of the difficulty hitherto experienced. The gummy substance thrown by the tannic acid was tested qualitatively for phosphorus. A positive result was obtained. A biuret test for protein was also positive. On drying, this material took on the appearance of hard rubber, being jet-black, hard and lustrous.

Unfortunately, but one 0.2 per cent hydrochloric acid extraction was made on these samples, where as five were made in the other method. Hence, there was incomplete extraction of acid soluble materials. The acid filtrates from the edible portion and parings were each divided into two equal parts, after the tannic acid precipitate had been removed by filtration. These we shall designate as Edible Portions $A$ and $B$, and Parings $A$ and $B$. Edible Portion A.

To this portion was added four volumes of alcohol. A fine, white flakey precipitate resulted, but the quantity was appreciably less than in previous determinations where tannic acid had not been used. The substance, after filtering, was again dissolved in 0.2 per cent hydrochloric acid, and precipitated with the usual amount of alcohol. After filtering the next day, the precipitate was dried in a vacuum desiccator over sulphuric acid for twenty-four hours. A fine, light-gray powder resulted. The substance was soluble in water, and its aqueous solution was acid to litmus paper. 
When boiled with hydrochloric acid and neutralized, it reduced Fehling's solution and gave a positive test for pentoses with Bial's reagent. A quantitative phosphorus determination was made.

\section{TABLE XIII.}

Fraction 2, Tannic acid -alcohol method, Edible Portion. Gms. Frac 2. $\operatorname{Mg}_{2} \mathrm{P}_{2} \mathrm{O}_{7} \quad \mathrm{P}_{2} \mathrm{O}_{5} \quad \mathrm{P}$ Pct. $\mathrm{P}_{2} \mathrm{O}_{5}$ Pct. of $\mathrm{P}$ used grams grams. grams grams in frac. 2 in frac 2. $\begin{array}{lllllll}50.0879 & .0252 & .0146 & .0094 & .0041 & 38.3 & 16.7\end{array}$

The percentage found is higher than that usually attributed to phytin, i.e., 14 per cent. According to Anderson! when the tannic acid method is used, the resulting substance is sightly different in composition from that obtained in the first method. In his determination of wheat bran by thismethod, the phytin contained 15.23 per cent phosphorus; the substance, however, had been five times purified, whereas this had been but twice purified. It will be observed that in our phosphorus determination of the wheat bran phytin, ( $p 36$ this paper), where five purifications were ade, the percentage of phosphorus was higher than when only two purifications were made. Hence we cannot assume that inorganic phosphorus is still in the above organic phosphorus compound, causing this discrepancy. Edible Portion B.

To this half of the 0.2 per cent hydrochloric acid filtrate, a solution of barium chloride was added which caused IJourn. Biol. Chem. Vol XII, p 462. 
a small precipitate to form. In equal quantity of alcohol was added, the mixture well stirred and left over night. The resulting precipitate was much greater than in $A$. After filtering, the precipitate was dissolved in 0.5 per cent hydrochloric acid and precipitated with an excess of bariumhydroxide. Upon filtering, the precipitate was dissolved in 0.5 per cent hydrochloric acid and precipitated with an equal volume of alcohol. The substance, after filtering, was again dissolved in 0.5 per cent hydrochloric acid and precipitated with barium hydroxide, and then once more from 0.5 per cent hydrochloric acid with alcohol. The product did not give any reaction with ammonium molybdate, showing the substance to be free from inorganic phosphates. The material dried in a desiccator over night, weighed .0354 grams. It was appreciably greater in quantity and of a darker gray color than the material obtained from $A$. When dissolved in water it also gave an acid reaction to litmus paper, but was noticeably more acid than $\mathbf{A}$. When boiled with hydrochloric acid and neutralized, it reduced Fehling's solution and gave the pentose test with Bial's reagent. A quantitative determination was made.

\section{TABLE XIV.}

Fraction 2, Tannic acid-Barium chloride Method, Edible Portion. gms. Frac 2. $\operatorname{lig}_{2} \mathrm{P}_{2} \mathrm{O}_{7} \quad \mathrm{P}_{2} \mathrm{O}_{5} \quad \mathrm{P}$ Pct. $\mathrm{P}_{2} \mathrm{O}_{5}$ Pet. of $\mathrm{P}$ used grams grams grams grams in frac. 2 in frac 2.

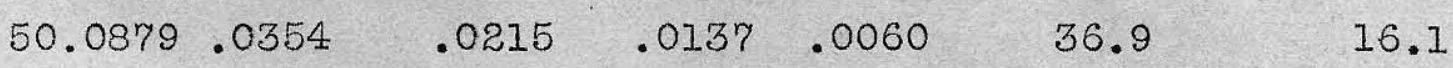

Here again the percentage of phosphorus is higher than in the phytin from wheat bran obtained by Anderson (10.8\%). with the aid of Barium chloride. 
Parings A.

The procedure with this portion was identical with that of edible portion A. After stirring, upon the addition of the usual quantity of alcohol, a more voluminous precipitate quickly formed. It was also flakey, but somewhat darker in color. The precipitate settled in a short time, leaving the alcohol-acid mixture clearer and lighter in color than it was prior to the addition of the alcohol. After filtering through hardened filter paper, the precipitate was dissolved in 0.2 per cent hydrochloric acic as usual and precipitated with the required amount of alcohol. The resulting precipitate when dried and ground in a mortar, had the same physical appearance as the substance obtained in the corresponding experiment with the edible portion, except that the substance was of a darker gray color. It weighed .1382 grams, a noticeably greater quantity than in $A$ of edible portion. The aqueous solution gave the usual faint a cid reaction to litmus paper. Upon boiling with hydrochloric acid and neutralizing. with sodium hydroxide, Fehling's solution was reduced, and Bial's test showed the presence of pentoses.

\section{TABLE XV}

Fraction 2, Tannic acid-alcohol Method, Parings. Gms. Frac 2 $\mathrm{Mg}_{2} \mathrm{P}_{2} \mathrm{O}_{7} \quad \mathrm{P}_{2} \mathrm{O}_{5} \quad \mathrm{P}$ Pct. $\mathrm{P}_{2} \mathrm{O}_{5}$ Pct. of $\mathrm{P}$ used grams grams grams grams in frac 2. in frac 2.

$\begin{array}{lllllll}49.962 & .1382 & .0777 & .0499 & .0216 & 36.10 & 15.66\end{array}$

It will be observed that the percentage of phosphorus is comparable to that of the corresponding material from the edible portion. (p, 30$)$. 
Parings $B$.

The barium salt obtained by adding barium chloride to this portion and precipitating with an equal volume of alcohol, was of a dark brown color. Upon dissolving in 0.5 per cent hydrochloric and adding an excess of barium hydroxide, a dark, greenish-brown precipitate formed. The precipitate was quite bulky, but seon settled. Upon settling the precipitate changed in color to a dirty brown, leaving a vivid green coloration around its edge on the filter paper. When 0.5 per cent hydrochloric acid was poured over the filter paper and precipitate, this green color disappeared, and a large part of the precipitate remained undissolved. Upon filtration and precipitation with alcohol, a voluminous, white, flakey precipitate formed, and soon settled to the bottom of the beaker. The next morning it was filtered again, dissolved in 0.5 per cent hydrochloric acid, and precipitated with excess of barium hydroxide. After disșolving in excess of 0.5 per cent hydrochloric acid and precipitating with alcohol, it was filtered and the resulting substance dried in a desiccator over night. The quantity obtained weighed .2422 grams, being larger than in $A$. It was also darker in color. When boiled with concentrated acid and neutralized, it gave a reduction of Fehling's solution and also a positive test for pentoses with Bial's reagent. Its sollubility in water was noted and its strong acid reaction when in aqueous solution. A phosphorus determination made. Results appear in Table XVI, page 34.

The percentage of phosphorus is slightly lower than that given by Anderson in his phosphorus in the barium salt 
from wheat bran, but more nearly conforms with it than $B$ of the edible portion. This discrepancy in results is unexplained. There has not been time for repetition of these experiments. Fom the analyses of the substances obtained from the edible portion and parings by the method just described, we conclude that phytin, or some. substance closely related to it, is present in the potato. The phytin from wheat btan as obtained by Anderson, contained 14 per cent of phosphorus, when the material was prepared by alcoholic precipitation alone, and 10.8 per cent when prepared by precipitation with barium chloride.

\section{TABLE XVI.}

Fraction 2, Tannic acid-barium chloride Nethod, Parings. Gms. Frac 2. $\mathrm{Ng}_{2} \mathrm{P}_{2} \mathrm{O}_{7} \quad \mathrm{P}_{2} \mathrm{O}_{5} \quad \mathrm{P}$ Pct. $\mathrm{P}_{2} \mathrm{O}_{5}$ Pct. of $\mathrm{P}$ used grams grams grams grams in frac 2 in frac 2.

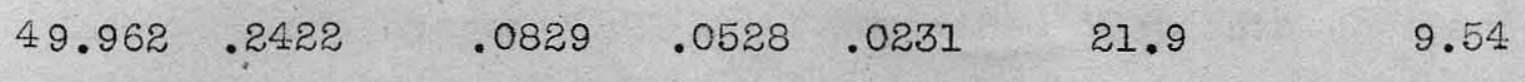

Comparison with Wheat Bran Phytin.

In order to familiarize ourselves with the properties of phytin and to test whether our method of extraction was at variance with that used in the wheat bran determination, we digested about 500 grams of bran with 0.2 per cent hydrochloric acid over night, strained and filtered the nixt morning, and precipitated with four volumes of 95 per cont alcohol. A heavy white precipitate resulted. This was filtered the next day and treated with 0.2 per cent hydrochloric acid and filtered. As an appreciable amount of the substance failed to dissolve. This substance, insoluble in acid, was similar 
in appearance to that which dissolved.

This acid solution was divided into two parts. One part was precipitated with alcohol and after filtering, the substance, (phytin), was dried in a vacuum desiccator in the dark for two days. The other half was subjected. four times more to solution in 0.2 per cent hydrochloric acid and precipitation with alcohol. The resulting substance was dried in the same manner.

Both substances obtained accorded with those described by Anderson' in their physical properties; the fine, white amorphous powder contrasting with the gray substances obtained from the potatoes. The aount left after five precipitations with alcohol was about half that left after only two precipitations. The loss was doubtless due to some of the material remaining in solution each time. Anderson found that the 0.2 per cent hydrochloric acid contained inorganic phosphates, and that the repeated precipitation of the substance from hydrochloric acid from alcohol was necessary. ${ }^{2}$. In testing the preparation which had been but twice precipit ted with alcohol for inorganic phosphates we obtained a flocculant, pale yellow precipit te, evidently organic, and inconclusive as to whether inorganic phosphate was present or not. The purer preparation gave a similar precipitate when tested.

Quantiative phosphorus deteminations were made. The short timerequired for the oxidation of the organic matter was a noticeable feature in this part of the work. $A_{n}$

I Journ. Biol. Chem. Vol XII, p 454. ¿Ibid. 
hoar was quite sufficient. The initial amounts of acid used were respectively ten and fiften c.c. of sulphuric and nitric acids. The reaction was not at all violent. When the mass darkened and charred, it was allowed to cool, and ten c.c. more of nitric acid added and the mixture boiled. The mass became entirely clear. It was allowed to boil for thirty minutes. No residue of any kind was observed. The mixture was as clear as distilled water. To insure complete decomposition, another ten c.c. of nitric acid was added, and the contents boiled. The phosphorus determination was then continued as usual. To make a complete precipitation of the phosphates, 125 c.c. of ammonium molybdate was necessary.

\section{TABLE XVII.}

Phytin from wheat Bran.

Bran used Phytin Phytin $\operatorname{Mg}_{2} \mathrm{P}_{2} \mathrm{O}_{7} \quad \mathrm{P}_{2} \mathrm{O}_{5} \quad \mathrm{P}$ Pct. P in Pct. $\mathrm{P}_{2} \mathrm{O}_{5}$ grams obtained used grams grams grams phytin in phytin.

$\begin{array}{rrrrrrrr}A^{\prime} & 4.9502 & 1.1747 & 0.5620 & .3590 & .1570 & 13.4 & 30.6 \\ 250 & & & & & & & \\ B^{2} & 2.5593 & 0.2334 & 0.1200 & .0765 & .0335 & 14.4 & 32.8 \\ 250 & & \end{array}$

Twice precipitated. 2.Five times precipitated.

The results obtained compare closely with those of Anderson, i.e., 14 per cent phosphorus. It is also noteworthy, that the material which had been only twice precipitated with alcohol does not differ in phosphorus content to a very great extent from that precipitated five times with alcohol. The very low percentage of phosphorus, found habitually in the acid soluble-alcohol insoluble fraction from potatoes, indicates, 
therefore, that this material is of a markedly different nature from the corresponding material from bran, and is not to be considered merely as a crude phytin fraction, although there is some phytin in it $(p)$. That this fraction which was free from inorranic phosphates, contains other phosphorus compounds also, is indicated by the fact that the phosphorus left in solution after the abowe tannic acid and barium chloride treatment in both edible portion and parings was greater in amount than that found by simple alcoholic precipitation, i.e,, the phosphorus of fraction three was greater when this method of separating fraction two was empolyed as shown in the following :

Tannic Acid Method for Fraction 2,

Fraction $3 \mathrm{P}$ from $100.1759 \mathrm{~g}$. edible portion $.0975 \mathrm{~g}$. Percentage of dried edible portion Fraction 3 P from $99.924 \mathrm{~g}$. parings $.097 \%$ Percentage of dried parings .13458 . $.13 \%$

Simple Alcoholic Precipitation of Fraction 2.

Fraction 3 P from $101.0142 \mathrm{~g}$. edible portion . $0945 \mathrm{~g}$. Percentage of dried edible portion $.093 \%$

Fraction 3 P from 99.924 g. parings $.1289 \mathrm{~g}$.

Percentage of dried parings $.12 \%$

The finding of phosphorus in a tannic acid precipitate also indicates that there are various compounds of phosphorus in fraction 2 . 
3- Acid soluble-alcohol soluble Fraction.

Little was learned regarding the nature of this fraction. It was rich in organic material as noted in the decomposition process. Whether organic phosphorus is present, and if so, to how great an extent, remains for future investigation to decide. It presumably consists largely of inorganic phosphates.

4- Residual Phosphorus.

This fraction was likewise not investigated, except that further extractions with 0.8 per cent hydrochloric acid yielded no inorganic phosphate. The large amount of phosphorus left in this fraction in each determination is presumably mostly mostly protein phosphorus, but it is impossible to state at present whether or not other phosphorus compounds are likewise present.

A tabulated survey of the phosphorus compounds of the edible portion and parings treated by the tannic acid method, and a comparison of the sum of the four fractions with the total phosphorus as obtained, ( $p$ 11), follows in Tables XVIII and XIX on page 39.

By comparison of Tables XVIII and XIX, page 39, we findthat the tannic acid causes a decrease of phosphorus in fraction 2, while an increase is noted in fraction 3 , but the difference is so. slight as to be inadmissible. 


\section{TABLE XVIII.}

\section{Edible Substance (100.1759 g).}

Fractions

Divisions

$\begin{array}{lr}\mathrm{Mg}_{2} \mathrm{P}_{2} \mathrm{O}_{7} & \mathrm{P}_{2} \mathrm{O}_{5} \\ \text { grams } & \text { grams }\end{array}$

$P$

Pct. of total phosphorus

1- Lipoid

Acid sol-

2- alc insol substance

Acid sol-

3- alc sol substance

4- Residual P

Total

Estimated from total $\mathrm{P}$ deter.

$\begin{array}{llll}.0653 & .0417 & .0182 & .9 .05\end{array}$

$\begin{array}{llll}\text { Part I } & .0146 & .0094 & .0041\end{array}$

Part II $\quad .0215 \quad .0137 \quad .0060$

$\begin{array}{lllll}\text { Total } & .0361 & .0231 & .0101 & 5.02\end{array}$

Part I. $.1749 \quad .1111 \quad .0487$

Part II $\quad \begin{array}{lll}.1606 & .1024 & .0488\end{array}$

Total

$.3355 \quad .2135 \quad .0975$

48.53

$\begin{array}{llll}.2911 & .1857 & .0811 & 40.36\end{array}$

$\begin{array}{llll}.7280 & .4640 & .2069 & 102.96\end{array}$

$.7271 \quad .4599 \quad .2009$
TABLE XIX.

Parings $(99.924 \mathrm{~g})$.

Fractions Divisions $\quad \mathrm{Mg}_{2} \mathrm{P}_{2} \mathrm{O}_{7} \quad \mathrm{P}_{2} \mathrm{O}_{5}$ grams grams

1- Lipoid

Acid sol-

2- alc insol substance

Acid sol-

3- alc sol

substance

4- Residual P

Total

Estimated from

total $\mathrm{P}$ deter.
$.0480 \quad .0325 \quad .0142$

4.43

Part

$.0777 \quad .0499$

.0217

Part II $\quad .0829 \quad .0528 \quad .0231$

$\begin{array}{llll}\text { Total } & .1606 & .1027 & .0448\end{array}$

13.99

Part I $\quad .2433 \quad .1545 \quad .0675$

Part II $\quad \begin{array}{llll}.2406 & .1535 & .0670\end{array}$

$\begin{array}{lll}\text { Total } & .4829 & .3080\end{array}$

41.99

$.4180 \quad .2667 \quad .1165$

36.35

$\begin{array}{lll}1.1095 & .7099 \quad .3100\end{array}$

96.76

$\begin{array}{lll}1.1177 & .7354 \quad .3205\end{array}$ 


\section{Summary .}

1- The results obtained lead us to think that the method pursued is perhaps effectual in the separation of the four types of phosphorus compounds. We realize that the data submitted do no prove this conclusively, but we believe add much evidence in favor of the assertion. Nore data must be accumulated and more extensive investigation made, before the method can be considered reliable.

2- The phosphorus in the edible pottion was found to be distributed among the four classes of phosphorus compounds a.s follows, i,e., (1) Fraction 1, (Lipoid), 8.2 per cent; (2) Fraction 2, (Acid soluble-alcohol insoluble), 7.3 per cent; (3) Fraction 3, (Acid soluble-alcohol soluble) 47.25 per cent; (4) Fraction 4, (Residual Phosphorus), 39.25 per cent.

3- The phosphorus content of the parings is shown to be appreciably higher than in the edible portion. Of the total phosphorus of the whole potato, 22.46 per cent is in the parings; 77.54 per cent in the edible portion, as ordinarily pared. The phosphorus of the parings is distributed among the four classes of phosphorus compounds as follows, i.e., (1) Fraction 1, (Lipoid) 4.36 per cent; (2) Fraction 2 (Acid soluble-alcohol insoluble), 7.03 per cent; Fraction 3, (Acid soluble-alcohol soluble), 43.21 per cent: (4) Fraction 4, (Residual Phosphorus), 39.91 per cent. 4- A phytin-like substance with a phosphorus content of about 16 per cent was obtained from both edible portion and parings. 